\title{
Empirical Analysis of the Connection between Financial Performance and Corporate Governance within Technology Companies Listed on NASDAQ Stock Exchange
}

\author{
Georgeta Vintilă and Radu Alin Păunescu \\ Department of Finance, Bucharest University of Economic Studies, Bucharest, Romania
}

Correspondence should be addressed to: Radu Alin Păunescu; radupaunescu696@gmail.com

Received date: 25 February 2016; Accepted date: 6 June 2016; Published date: 6 October 2016

Academic Editor: Nicoleta Bărbuţă-Mişu

Copyright (C) 2016. Georgeta Vintilă and Radu Alin Păunescu. Distributed under Creative Commons CC-BY 4.0

\begin{abstract}
The present research gives an insight on the connection between corporate governance and financial performance, using companies from technology sector listed on NASDAQ, during 2010-2013. Financial performance was measured using as proxy the return on equity (ROE) and the return on assets (ROA). For the corporate governance measures there were selected variables as seniority, duality, and remuneration of the CEO, independence, size and gender diversity related to Boards of Directors. For empirical tests we used multivariate regression models, generalized least squares (GLS) and standard error correction for heteroskedasticity using White's method. The results have confirmed the influence of mixed corporate governance variables on financial performance indicators at the company level. We obtained in both models a positive influence on financial performance from variables age, years listing and CEO's remuneration with bonuses. We obtained negative influence for the variables size / independent members of the Board of Directors and for the CEO duality. The difference between the two models was marked by the positive influence of the percentage of women in the Board of Directors' members and the CEO salary on ROA. The Risk Commitee variable had a negative influence on ROE. The control variables had a positive influence only on the ROE model. The final conclusions highlight issues related to human nature such as the lack of fear for penalty, which can lead to the loss of use of rationality and morality. Exploring the corpoarte governance, there can be identified facts which can lead to dangerous behavior if eople have a significant decision-making power.
\end{abstract}

Keywords: corporate governance, financial performance, econometrics

JEL Classification: G32, G34

Cite this Article as: Georgeta Vintilă and Radu Alin Păunescu (2016)," Empirical Analysis of the Connection between Financial Performance and Corporate Governance within Technology Companies Listed on NASDAQ Stock Exchange", Journal of Financial Studies \& Research , Vol. 2016 (2016), Article ID 629934, DOI: $10.5171 / 2016.629934$ 


\section{Introduction}

The 2007s represented for the US economy, but also for the entire world, the triggering of the famous financial crises. After the Great Crash of 1929 it would have been expected that this kind of events will not be repeated anymore and the participants from the financial market will take protective measures. But human nature, greed, globalization and derivative instruments, all combined, have pulled the alarm within financial markets, leaving behind a hard lesson to forget. Kotler and Casoline (2009) believe that with the 2007s we have entered into "a new era of turbulence" in which the cyclicality has been replaced by the uncertainty (and the economic and financial environment became "chaotic").

The academic literature contains numerous papers describing the causes and effects of the 2007's crisis, but the purpose of this paper is to analyse the corporate governance for US companies that are found listed on NASDAQ market and also are components of the dow jones index.

The paper seeks to identify if and how companies have implemented corporate governance rules in the period after the crisis. Viewed from the crisis perspective, it can be said that corporate governance was ineffective, but at a closer look it can be seen that there has been a lack of attention to the rules imposed by it. Apart from the link between corporate governance and financial performance, the novelty of this research study is the attention to the idea of moral hazard and voracity for earnings without regard to corporate governance. This study is important because it highlights the meaning of corporate governance within capital markets and its influence on the financial performance of listed companies. Another important issue followed in this paper is the research of human nature, which loses its use of reason when there is no fear of being penalized. This is a dangerous behavior if people have a significant decision-making power (for example the CEO duality inside of a large company).

The rest of the paper is structured as follows: Section 2 presents significant works of literature aimed to the proposed topics. Section 3 contains the assumptions chosen for the econometric research. Section 4 includes the presentation of the methodology chosen to investigate the influence of corporate governance on the financial performance of the company and how it could interfere with the realationship of the shareholders managers. Section 5 contains the results of the econometric study. The last section contains conclusions on corporate governance, results and proposals for future research.

\section{Prior research about corporate governance in academic literature}

Monks and Minow (2011) define corporate governance as a tool for warning and risk prevention, used by managers in the benefit of shareholders. Such risks can also affect the community, an idea supported by Haldane (2011) who said that in the 13th century the bankers had been bankrupted banks and now they are bankrupting more than banks, referring to the 2007's crisis. Bebchuk and Fried (2003) noted contrary to economic theory that the managers' goal is not necessarily to maximize the shareholder wealth, a fact which leads to asymmetry of information. Empirical evidence obtained by Lee et al (2013) supports the idea that the application of the rules of corporate governance codes can reduce the asymmetry of information. Kanagaretnam et al (2007) defined corporate governance as the combination of procedures to ensure the protection of both the majority and the minority shareholders. To better understand this problem, one must start from its roots. Turner (2009) presents the Anglo-Saxon financial and banking system from the 19th century which was composed of majority stakeholders ("low concentration") and with total power control ("unlimited liability partnerships"). Being the majority shareholders, they literally risked their

Georgeta Vintilă and Radu Alin Păunescu (2016), Journal of Financial Studies \& Research, DOI: $10.5171 / 2016.629934$ 
own fortune, so they were more disciplined with the clients' deposits. This may be the reason why corporate governance has emerged so late. But the Industrial Revolution and modern society were constantly expanding so the development of railways was needed and massive capital investments were required. Owners of banks were not willing to take the risk and they didn't allow loans. Thus, in the second half of the 19th century, the United States was the first state who adopted the socalled "limited liability" which allowed dividing the equity to a greater number of shareholders, paving the way to the actual capital markets, but the Pandora's box of financial irregularities was opened. Then it was perhaps the right moment to impose the corporate governance code but they didn't do it.

Another problem pursued is specified by the Executive Director of Financial Stability at the Bank of England, Haldane (2011) who said that in 1989 the CEO rewards of the largest US banks were 100 times higher than the average income of a household. By 2007 it had become 500 times bigger. This spectacular increase is not due to the imposition of the corporate governance but contrary to the fact that CEOs have minimized the extent of the risk of noncompliance. The American Corporate Governance Code suggests that managers' salaries should reflect performance and seniority, but should not exceede one million dollars in order to be tax efficient. This situation is specific to companies deemed "too big, to fail". Haldane (2011) noted that the importance of corporate governance was belittled without taking into consideration the risk, a fact which eventually led to the crisis.

The academic literature analyzes corporate governance from several perspectives. The main empirical studies include CEO characteristics, characteristics of the Board of Directors, the CEO remuneration and other transmission mechanisms of corporate governance within a company. The authors devoted to studies of corporate governance are Shleifer and Vishny (1997), La Porta et al (1999), Drobetz et al (2003) and others. Most of the papers have focused mainly on the characteristics of the Board of Directors. Adams and Ferreira (2007) considered as tasks of the Board the activity of monitoring the way where the company "goes". Boone et al (2007) examined this fact, based on two assumptions regarding the Board of Directors. The first assumtion considers that the Board is often ineffective, and should be regulated in order to increase the financial performance of a company. The second scenario considers the Board of Directors as part of the company, noting that it should be structured according to company characteristics and the business environment in which it operates to achieve higher performance. Boone et al (2007) concluded that the Boards of Directors have adjusted themselves to respond effectively to the characteristics of the companies, with a dynamic management strategy that takes into account the cost of monitoring the managers. Their companies have become more competitive and hence, more efficient by reducing the information asymmetry. Mashayekhi and Bazaz (2008) obtained a positive correlation between governance and performance and they have theorized that an effective Board of Directors can significantly reduce the cost derived from the agent problem. Beside informational asymmetry and agency costs, many authors, including Core and Larcker (2002), noted that elements of corporate governance influence the company's value. Correlating the two ideas with ownership structure and the board members who hold shares in that company, they highlighted the theory proposed by Jensen and Meckling (1976) and the bond between governance and financial performance. Armstrong et al (2015) examined the link between governance and financial performance, focusing on legal tax avoidance and on the incentives of the managers. Although initially they did not obtain a significant link between governance and tax avoidance, using quantile regressions, they have identified a positive relationship between the number of independent members of the Board of Directors and the reduced levels of tax avoidance. On the other hand, Armstrong et al (2015) have 
found that the use of high level of tax avoidance has a negative relation with the number of independent members. Thus, one can believe that non-executive members accept the use of legal tax avoidance in reduced conditions to get a higher financial performance, but they don't allow these methods to be used excessively for they could adversely affect the company, and hence, the shareholders. Itturalde et al (2011) obtained a nonlinear relation between ownership structure and the corporate value. The idea is supported by Erkens et al (2012) who showed that firms with Boards of Directors with more non-executive members and which were held (from number of shares) mostly by institutional investors had the worst returns during the crisis. Beekes et al (2010) showed that firms which include a large number of members in the Board of Directors had a negative link between their number and the economic profitability. AlNajjar (2013) studied the link between governance and financial performance based on three indicators: ROA (return on assets), ROE (return on equity) and Market-to-book ratio. The results showed that the role of independent members is statistically significant on both profitability indicators ROA, ROE and on the performance indicators from stock market. Al-Najjar (2013) concluded that corporate governance positively influences a company's financial performance only if it is supported by the macroeconomic conditions of the industry. The theories support the idea that corporate governance is better applied if in the Board of Directors there are representatives of institutional investors. Bushee et al (2013) studied corporate governance from the perspective of institutional investors but they did not obtain clear evidence to support this theory. McCahery et al (2010) studied the issue of institutional investors for US companies and they noted that institutional investors prefer companies where corporate governance has an active connection with the financial performance. Loderer and Waelchli (2011) believed that as a company matures, the financial performance declines, especially in the technology sector which is in a continuous development. This is reflected by a lesser degree of economic rentability and a lower market share because the company can not grow more. Li and Maksmovic (2010) considered that companies from industries that can not have a very high maturity, such as the technology sector which advances continuously, the trend is to choose managers who are known for their performance in other areas, but they do not have the expertise to get a notable financial performance.

Another issue debated in academic literature is the CEO compensations. The statistics compiled for 2014 by Investor Responsibility Research Center Institute (IRRCi) for companies in the S\&P 1500, showed that $90 \%$ of directors are remunerated based on the accounting results obtained in less than three years and only $12 \%$ of the remunerations were based on financial performance indicators. Thus, it is not surprised the long-term impact on financial performance of the managers' decisions. In the USA, for determining the remuneration it is taking into account the protection of shareholders' interests and the idea of maximizing their wealth. Thus, the Board of Directors must adopt a transparent remuneration policy that reflects the longterm interests of shareholders but also takes into account the remuneration paid in previous years. Ozkan (2006) observed that CEOs who are overseen by a big Board of Directors with many independent members, receive higher wages, a fact which suggests that a large number of independent members is not necessarily effective in monitoring activity. Bhagat et al (2010) concluded about the remuneration that it is not appropriate to settle the pay level according to the academic studies of the manager. Another work performed by Frydman and Jenter (2010) showed that a better observation of the impact of the CEO remuneration is through the revaluation of stocks and options' packages which are awarded to the manager. Thus, the CEO is directly involved in company and he will want to achieve a better financial performance. El Baroudy et al (2008) obtained in an econometric research study that remuneration as bonuses and stock packages is closely linked with the 
company's size and financial performance but the basic salary is not correlated with the financial performance. Honoré et al (2015) have investigated the connection between corporate governance and financial performance in terms of the link between investments and research and development expenses made by the manager and the interests of shareholders. In other words, they analyzed the relationship governance - performance starting from asymmetry of information. Honoré et al (2015) obtained results which had showed a negative link between remuneration based on the financial performance and the shareholders' right to vote for investment in research and development. In other words, it was observed that corporate governance practices have no influence on decisions regarding the CEO's long-term investments in research and development.

Coates and Kraakman (2010) have studied the issue of tenure for the CEO post and they observed that there are certain patterns about the leading positions influenced by the degree in which the company is able to merge or be taken over by another company.

OECD published the Corporate Governance Factbook for the year 2014 which contains details about corporate governance within the OECD members. According to the report, the US is alongside Australia and the UK characterized by a dispersed ownership structure (see Holderness et al, 2010). Members of the Board of Directors are elected every three years or are reelected annually and the number of independent members depends on the ownership structure.

Another part of the literature focuses on the existing committees within the company. They may be audit, nomination and remuneration committees. After the crisis of 2007, a new form of committee arose, the risk committee. Albring et al (2013) studied the issues regarding the committees in the context of governance performance. Albring et al (2013) have noticed that, where are more independent members, audit committee with members who have higher expertise in financial accounting and CEO duality, companies have more financial perfomance. They also prefer to issue more new shares. Thus, a better accounting expertise provides a higher monitoring from the audit committee, yielding a higher financial performance, fact which indicates a positive influence on the part of corporate governance. Aebi et al (2012) have studied the link between governance and financial performance for companies in the banking sector. They wanted to identify how the elements of corporate governance reacted to the danger which threatened the financial performance of selected companies and even their very existence. Among the governance variables analyzed, it were counted the presence of the chief risk officer, CRO, and if he answers to the Board of Directors or to the CEO. The aim was to find the existence of a direct link between risk and financial performance. Aebi et al (2012) considered as proxy for financial performance, ROE and the returns of buy-and-hold shares and for governance structure they took the board members and the ownership structure. The study results showed that the companies, in which the CRO reports directly to the Board of Directors, recorded a higher level for ROE and yields during the crisis. The novelty of the study was the fact that the authors have shown that in the crisis context, the classical governance variables do not capture a significant impact on financial performance and it is more useful to be made variables that contain the risk element. Giannetti and Yafeh (2012) showed that the variables of corporate governance must reflect the characteristics of the credit system to capture a broader influence on financial performance. Stulz and Williamson (2003) showed that the opening level of the financial environment and the cultural level of the Board's members have influence on financial performance. Bae et al (2010) showed that the dividend distribution rate is important for studying the link between governance and performance.

Gupta et al (2013) studied the impact of corporate governance on the financial performance of US companies. The results 
showed that companies with a good corporate governance are not necessarily performing better, in financial terms, compared to companies that have a less developed corporate governance. Gupta et al (2013) identified three possible causes for these results. The first said that the differences in institutional development affect the impact of governance on financial performance. The second one is based on the fact that during the crisis there has been a reduction in the informational efficiency of capital markets, which distorted the influence of governance, because each company has waited the crisis impact. How smaller companies were not confined by the restrictive conditions imposed by the Boards of Directors from the big companies, they took riskier financial decisions, but they have brought benefits reflected in better financial performance. Thus, there was a balance between companies with developed but restrictive governance and companies with a less developed corporate governance. Erkens et al (2012) have investigated the influence of corporate governance on financial performance during the crisis of 2007. They observed that firms with more independent members and more institutional investors inside the ownership structure have recorded poor yields. This supports the idea that these governance structures were anchored against the risk without seeking solutions to increase the financial performance, a fact which had a negative effect on performance. Another negative effect induced by the large number of independent members was the increase of indebtedness which resulted in a transfer of the shareholders' wealth to the creditors. Beltratti and Stulz 2012) observed that the Board of Directors focused only on the interests of shareholders, had a negative impact on financial performance. Ammann et al (2011) found a positive link between corporate governance and financial performance represented by the company's value. The study results showed that the proper application of corporate governance will be reflected in higher market values. They also found that it is cheaper and more appropriate to apply corporate governance mechanisms than to implement methods for monitoring the managers, resulting in higher cash flows for shareholders and lower capital costs. Another aspect studied by the literature is the share of women in the Board of Directors. Adams and Ferreira (2009) believe that women are more prone to join the monitoring committee of the company. Khan and Vieito (2013) showed that companies with women as CEOs have took less risky decisions and thus, the financial performance, measured by ROA, was higher.

\section{The assumptions chosen for the empirical research}

The main aim of the research is the connection between corporate governance and financial performance for the NASDAQ listed companies in the technology sector. Starting from the models shown in the literature, we have established the following assumptions for empirical research:

- Hypothesis $1\left(\mathrm{H}_{1}\right)$ : The existence of a positive link between the share of women in the Board of Directors and financial performance (Fidanoski et al, 2013)

- Hypothesis $2\left(\mathrm{H}_{2}\right)$ : The existence of a negative link between the number of nonexecutive members (independent) and financial performance (Erkens et al, 2012; Guest, 2008; Metrick and Ishii, 2002; Hermalin and Weisbach 2003)

- Hypothesis $3\left(\mathrm{H}_{3}\right)$ : The existence of a positive link between the CEO's remuneration and financial performance (Kang et al, 2006; Perry, 2000)

- Hypothesis $4\left(\mathrm{H}_{4}\right)$ : The existence of a negative link between the CEO's duality and financial performance (Erkens et al, 2012)

- Hypothesis $5\left(\mathrm{H}_{5}\right)$ : The existence of a positive link between the size of Board and financial performance (Al Najiar, 2013; Adams and Merhan, 2005)

- Hypothesis $6\left(\mathrm{H}_{6}\right)$ : The existence of a negative connection between the CEO's tenure and financial performance (Berger et al, 2014) 
- Hypothesis $\left(\mathrm{H}_{7}\right)$ : The existence of a positive link between the presence of the risk committee and financial performance

- Hypothesis $8\left(\mathrm{H}_{8}\right)$ : The existence of a link between the year of listing on the stock market and financial performance

\section{Econometric research metodology}

\section{Database and variables' description}

The empirical analysis is to identify the existence of a correlation between financial positions of NASDAQ listed companies and corporate governance. Another topic of interest is the extent to which CEOs of the most powerful US companies follow the Governance Code and the rules of corporate governance. The period under review covers the $2010-2013$ representing post 2007's crisis when governance has become a necessity. Although it is a relatively large difference between the crisis triggering year and the analyzed period, this difference is not random. We considered that the 2010 was the first year in which companies should start normal operation after the tumult of the crisis. The purpose was to analyze the CEO's reaction on corporate governance and what measures they took to avoid another crisis. The sample analyzed comprises 51 companies, of which 27 companies belong to the Dow Jones and 24 to NASDAQ (chosen at random), aiming to relatively equal proportions. As a result of this, we registered a total of 205 statistical observations. The selected companies are majority from the technology sector, except companies like McDonald's and Coca Cola which we retained in analysis due to their significant importance. The contagion effect of volatility within capital markets, and the fact that many investors have diversified portfolios made us keep those companies. We excluded the financial companies like Goldman Sachs, JP Morgan and Visa.

The data source is the annual accounts statements available on Thomson Reuters Eikon's platform, as well as the reports that include ownership structure, and other information necessary to achieve corporate governance variables. We also used the websites of companies to establish corporate governance variables.

The description of the variables used in the empirical study is presented in Table 1. 
Table 1: Description of variables used

\begin{tabular}{|c|c|}
\hline Variables & Description variables \\
\hline \multicolumn{2}{|c|}{ 1.Dependent variables - Financial Performance } \\
\hline ROA (\%) & $\begin{array}{l}\text { Net Income / Total Asset } \\
\text { The economic return, ROA expresses the ability of the CEO to } \\
\text { generate income by using the total asset invested by the } \\
\text { shareholders. It may be associated with the internal rate of } \\
\text { return, IRR. }\end{array}$ \\
\hline ROE (\%) & $\begin{array}{l}\text { Net Income / Total Equity } \\
\text { The financial return, ROE expresses the performance through } \\
\text { the eyes of the shareholders. It shows the capacity of the } \\
\text { company to distribute dividends or to reinvest the profit. }\end{array}$ \\
\hline \multicolumn{2}{|c|}{ 2. Independent variables - Corporate Governance } \\
\hline BONUS_CEO & It is computed as ln (Bonuses and compensations) \\
\hline CEO_DUAL & $\begin{array}{l}\text { It is a dummy variable equal to } 1 \text { if the CEO is the Chairman of } \\
\text { the Board of Directors or equal to } 0 \text { if he is not the Chairman }\end{array}$ \\
\hline BDSIZE & $\begin{array}{l}\text { The size of the Board of Directors. It is computed as ln (Total } \\
\text { number of the executives / insiders + total number of the non- } \\
\text { executives / independent / outsiders) }\end{array}$ \\
\hline BDFEM & $\begin{array}{l}\text { The ratio of the total number of women within the Board and } \\
\text { the total number of members from the Board of Directors. }\end{array}$ \\
\hline BDINDEP & $\begin{array}{l}\text { The ratio of non-exectutive members and the total number of } \\
\text { members from the Board of Directors }\end{array}$ \\
\hline RISKCOM & $\begin{array}{l}\text { It is a dummy variable equal to } 1 \text { if there is a Risk Committee } \\
\text { and equal to } 0 \text { if there is no Risk Committee }\end{array}$ \\
\hline SALARY_CEO & It is computed as ln (Base salary, no compensation) \\
\hline TENURE_CEO & The number of years since the CEO is leading in that function \\
\hline YLIST & $\begin{array}{l}\text { The number of years since the company was listed on public } \\
\text { markets }\end{array}$ \\
\hline \multicolumn{2}{|c|}{ 3. Independent Variables - Control Variables } \\
\hline SIZE & $\begin{array}{l}\text { It represents the size of the company computed as ln (Total } \\
\text { Assets) }\end{array}$ \\
\hline LEV & $\begin{array}{l}\text { Total Debts / Total Equity } \\
\text { Leverage shows the ability of the company to honour the long } \\
\text { term obligations. }\end{array}$ \\
\hline
\end{tabular}

The YLIST variable shows the age of the company, since the public listing on stock exchange markets. The USA have a system for financing companies, relied primarily on the capital market with high level of development, so that an American company may be regarded as being "effective", in terms of corporate governance, after the listing years. The role of corporate governance is to ensure the proper functioning of the company, in terms of managerial and financial performance, but from the perspective of investors, corporate governance is important because it shows the level of protection of minority shareholders.
Between the selected companies, we included large companies (MSFT) listed in the 80s when there was no impact of corporate governance and recently listed companies when governance was already implemented.Thus, it can be seen the impact of the corporate governance over the years. It should be noted that in the early years of the listing, a company has a high degree of concentration of ownership (3-4 major investors), and governance indicators are of interest to potential minority investors, along with the performance indicators. 


\section{The empirical methodology}

To analyze the relationship between corporate governance and financial performance of companies listed on NASDAQ stock market, we used date panel model, with multifactor regression and we estimated them using the least squares method (OLS). We used generalized least squares (GLS) and the standard error correction for heteroskedasticity using White's method. To test the hypotheses proposed in Section 3 of the paper we chose a multifactor regression in which differing only the independent variable which quantifies the performance (ROA, ROE). Basically, it is the same econometric model, the difference being made by financial performance variables.

The econometric model used:

1) Performance $_{i t}=\alpha+\beta_{1} \times$ BONUS_CEO $_{i t}+\beta_{2} \times$ CEO_DUAL $+\beta_{3} \times \mathrm{BDSIZE}_{\mathrm{it}}+\beta_{4} \times \mathrm{BDFEM}_{\mathrm{it}}+$ $\beta_{5} \times$ BDINDEP $_{i t}+\beta_{6} \times$ $\mathrm{RISKCOMC}_{\mathrm{it}}+\beta_{7} \times$ SALARY_CEO $_{\text {it }}+\beta_{8} \times$ TENURE_CEO $_{i t}+\beta_{9} \times$ YLIST $_{i t}+$ $\beta_{10} \times \mathrm{SIZE}_{\mathrm{it}}+\beta_{11} \times \mathrm{LEV}_{\mathrm{it}}+\mathrm{e}_{\mathrm{it}}$ where:

$\alpha$ is the intercept; is the constant parameter that quantifies the influence of all the variables not included in the model on financial performance

$\mathrm{i}=$ the 51 companies listed on NASDAQ stock market, chosen for the econometric models

$e_{i t}$ is the residual term or the error term which quantifies the influence of the random factors nonincluded in the model

In Table 2 there is attached the Descriptive Statistics to capture some of the key statistical information that may be immediately seen to the data. The number of observations is 204. The Descriptive Statistics show that the size of the Board of Directors varies between 12 and 32 members; the maximum CEO's tenure was 26 years (stock symbol EPIQ); an interesting fact is the percentage of women in the total number of members from the Board. The percentage has a high variation, switching from $0.0 \%$ for Astro-Med Inc (ALOT) to the maximum value of $42 \%$ registered by Procter \& Gamble Company (PG)

Table 2: Descriptive Statistics

\begin{tabular}{|c|c|c|c|c|c|c|c|c|c|c|}
\hline Variabile & Mean & Median & Max & Min & $\begin{array}{c}\text { Std. } \\
\text { Dev. }\end{array}$ & Skewness & Kurtosis & $\begin{array}{c}\text { Jarque- } \\
\text { Bera }\end{array}$ & Prob & Obs. \\
\hline ROA & 0.12 & 0.11 & 0.38 & -0.07 & 0.07 & 0.73 & 3.57 & 20.99 & 0.00 & 204 \\
\hline ROE & 0.21 & 0.17 & 0.35 & -0.17 & 0.18 & 3.17 & 18.25 & 2319.52 & 0.00 & 204 \\
\hline BONUS_CE0 & 7.45 & 9.71 & 15.83 & 0.00 & 7.19 & -0.04 & 1.06 & 31.38 & 0.00 & 200 \\
\hline BDSIZE & 2.88 & 2.89 & 3.50 & 2.08 & 0.36 & -0.15 & 2.07 & 8.06 & 0.02 & 204 \\
\hline CEO_DUAL & 0.55 & 1.00 & 1.00 & 0.00 & 0.50 & -0.22 & 1.05 & 34.02 & 0.00 & 204 \\
\hline LEV & 0.69 & 0.29 & 18.85 & 0.00 & 1.56 & 8.24 & 92.57 & 70493.65 & 0.00 & 204 \\
\hline BDFEM & 0.19 & 0.20 & 0.47 & 0.00 & 0.10 & -0.28 & 2.87 & 2.80 & 0.25 & 204 \\
\hline BDINDEP & 0.45 & 0.47 & 0.67 & 0.00 & 0.12 & -1.01 & 4.79 & 61.53 & 0.00 & 204 \\
\hline RISKCOM & 0.05 & 0.00 & 1.00 & 0.00 & 0.22 & 4.18 & 18.45 & 2622.73 & 0.00 & 204 \\
\hline SALARY_CE0 & 14.05 & 13.93 & 20.05 & 10.42 & 1.34 & 0.82 & 6.55 & 129.82 & 0.00 & 204 \\
\hline SIZE & 15.36 & 16.62 & 20.43 & 5.04 & 4.13 & -0.99 & 2.76 & 33.80 & 0.00 & 204 \\
\hline TENURE_CEO & 4.46 & 3.00 & 26.00 & 0.00 & 5.57 & 1.98 & 6.93 & 264.55 & 0.00 & 204 \\
\hline YLIST & 3.27 & 3.26 & 3.93 & 2.40 & 0.41 & -0.05 & 1.92 & 10.02 & 0.01 & 204 \\
\hline
\end{tabular}


We attached the Pearson Correlation Matrix inside Table 3 to observe the existent correlation in the data, and therefore the informational redundancy brought by them where there is a high correlation.

Table 3: Pearson's Correlation Matrix

\begin{tabular}{|c|c|c|c|c|c|c|c|c|c|c|c|c|c|}
\hline & 1 & 2 & 3 & 4 & 5 & 6 & & 8 & 9 & 10 & 11 & 12 & 13 \\
\hline Corr & $\begin{array}{c}\text { BONUS } \\
\text { _CEO }\end{array}$ & BDSIZE & CEO_DUAL & LEV & BDFEM & BDINDEP & $\begin{array}{c}\text { RISKC } \\
\text { OM }\end{array}$ & $\begin{array}{l}\text { SALARY_- } \\
\text { CEO }\end{array}$ & SIZE & TENURE_CEO & YLIST & ROE & ROA \\
\hline 1 & 1 & & & & & & & & & & & & \\
\hline 2 & 0.28 & 1.00 & & & & & & & & & & & \\
\hline 3 & 0.29 & 0.12 & 1.00 & & & & & & & & & & \\
\hline 4 & 0.14 & 0.21 & 0.19 & 1.00 & & & & & & & & & \\
\hline 5 & 0.05 & 0.23 & -0.10 & 0.03 & 1.00 & & & & & & & & \\
\hline 6 & 0.13 & -0.17 & 0.10 & 0.16 & 0.20 & 1.00 & & & & & & & \\
\hline 7 & 0.20 & 0.19 & 0.20 & 0.37 & 0.14 & 0.20 & 1.00 & & & & & & \\
\hline 8 & -0.10 & 0.27 & 0.00 & 0.07 & 0.05 & -0.08 & 0.08 & 1.00 & & & & & \\
\hline 9 & 0.27 & 0.58 & 0.19 & 0.24 & 0.22 & -0.04 & 0.16 & 0.40 & 1.00 & & & & \\
\hline 10 & -0.03 & -0.18 & 0.21 & 0.15 & -0.18 & 0.17 & 0.24 & -0.06 & -0.24 & 1.00 & & & \\
\hline 11 & 0.49 & 0.43 & 0.10 & 0.29 & 0.23 & 0.03 & 0.22 & 0.31 & 0.58 & -0.35 & 1.00 & & \\
\hline 12 & 0.00 & 0.14 & -0.13 & 0.28 & 0.05 & -0.08 & -0.02 & 0.17 & 0.30 & -0.26 & 0.37 & 1.00 & \\
\hline 13 & -0.01 & 0.06 & -0.35 & -0.14 & 0.19 & -0.18 & -0.10 & 0.27 & 0.08 & -0.24 & 0.18 & 0.39 & 1 \\
\hline
\end{tabular}

Source: Author's computations in Eviews 7

From Table 3 there can be observed some interesting correlations. Strong positive correlation is observed between the size of the Board of Directors (BDSIZE) and company size (SIZE). The two indicators are composed from different data and are different from an economic point of view. This correlation could be attributed to the fact that it is expected that a large company has a high number of directors on the Board.

\section{Results}

The first estimation contains the independent variable ROA. We estimate by OLS method and by using the generalized least squares (GLS). The correlation matrix results led us to apply the standard error correction for heteroskedasticity using White's method 
Table 4: Model 1 ROA

\begin{tabular}{|c|c|c|c|c|c|c|c|c|c|}
\hline & \multicolumn{3}{|c|}{ ROA } & \multicolumn{3}{|c|}{ ROA GLS } & \multicolumn{3}{|c|}{ ROA White } \\
\hline & $\begin{array}{c}\text { Coef. } \\
\beta\end{array}$ & $\begin{array}{l}\text { Std } \\
\text { Error }\end{array}$ & T-Stat & $\begin{array}{c}\text { Coef. } \\
\beta\end{array}$ & $\begin{array}{l}\text { Std } \\
\text { Error }\end{array}$ & T-Stat & $\begin{array}{c}\text { Coef. } \\
\beta\end{array}$ & $\begin{array}{l}\text { Std } \\
\text { Error }\end{array}$ & $\begin{array}{l}\text { T- } \\
\text { Stat }\end{array}$ \\
\hline BONUS_CEO & 0.00 & 0.00 & 1.25 & $0.00^{*}$ & 0.00 & 3.50 & 0.00 & 0.00 & 1.57 \\
\hline BDSIZE & -0.03 & 0.02 & -1.52 & $-0.02^{*}$ & 0.01 & -2.06 & $-0.03^{*}$ & 0.01 & -2.44 \\
\hline CEO_DUAL & $\underset{*}{-0.05}$ & 0.01 & -4.34 & $-0.04^{*}$ & 0.01 & -6.18 & $-0.05^{*}$ & 0.00 & -17.43 \\
\hline LEV & 0.00 & 0.00 & -1.21 & 0.00 & 0.00 & -1.20 & 0.00 & 0.00 & -1.13 \\
\hline BDFEM & $0.13^{*}$ & 0.05 & 2.54 & $0.15^{*}$ & 0.03 & 4.63 & $0.13^{*}$ & 0.02 & 8.86 \\
\hline BDINDEP & $-0.11^{*}$ & 0.04 & -2.59 & $-0.09^{*}$ & 0.03 & -3.24 & $-0.11^{*}$ & 0.02 & -6.72 \\
\hline RISKCOM & 0.00 & 0.03 & -0.03 & 0.00 & 0.02 & -0.23 & 0.00 & 0.03 & -0.03 \\
\hline SALARY_CEO & $0.02^{*}$ & 0.00 & 3.84 & 0.01* & 0.00 & 4.51 & $0.02^{*}$ & 0.00 & 4.87 \\
\hline SIZE & 0.00 & 0.00 & -0.74 & 0.00 & 0.00 & -0.22 & 0.00 & 0.00 & -1.62 \\
\hline TENURE_CEO & 0.00 & 0.00 & -0.81 & $0.00^{*}$ & 0.00 & -4.31 & 0.00 & 0.00 & -1.30 \\
\hline YLIST & $0.03^{* *}$ & 0.02 & 1.74 & 0.00 & 0.01 & -0.04 & $0.03^{* *}$ & 0.02 & 1.70 \\
\hline C & -0.05 & 0.07 & -0.71 & 0.04 & 0.04 & 1.00 & -0.05 & 0.05 & -1.11 \\
\hline
\end{tabular}

\begin{tabular}{|l|l|l|l|}
\hline \multicolumn{1}{|c|}{ R-squared } & 0.29 & 0.61 & 0.29 \\
\hline Adjusted R $\mathbf{2}^{\mathbf{2}}$ & 0.25 & 0.59 & 0.25 \\
\hline F-statistic & 6.99 & 27.11 & 6.99 \\
\hline Prob (F- stat) & 0.00 & 0.00 & 0.00 \\
\hline
\end{tabular}

Source: $\quad *$ variables statistically significant for a confidence level of $5 \%$

** variables statistically significant for a confidence level of $10 \%$

Names of the variables are presented in Table1

Author's computation in Eviews 7

Table 5:The significance of influence exerted on ROA by corporate governance variables

\begin{tabular}{|c|c|c|c|c|c|c|c|c|c|c|c|c|}
\hline & $\begin{array}{c}\text { BONUS } \\
\text { CEO }\end{array}$ & BDSIZE & $\begin{array}{c}\text { CEO } \\
\text { DUAL }\end{array}$ & LEV & BDFEM & BDINDEP & RISKCOM & $\begin{array}{c}\text { SALARY } \\
\text { CEO }\end{array}$ & SIZY & $\begin{array}{c}\text { TENURE } \\
\text { CEO }\end{array}$ & YLIST & C \\
\hline ROA & + & - & - & & + & - & & + & & + & + & - \\
\hline
\end{tabular}

Source: Author's computation in Eviews 7

The relevance of an estimator is bigger and it may be given a greater confidence if its dispersion is reduced (Std. Error). For the regression in which the financial performance is defined by ROA, standard errors indicate a high degree of confidence that can be associated to the coefficients. In Table 4 it can be found the model of determination ratio for ROA, which has values between $29 \%$ and $69 \%$, a fact that exceeds the $15 \%$ limit proposed by the econometric theory (see Andrei and Bourbonnais, 2008). The statistical inference involves applying the Student ttest which has a P-value less than $5 \%$ for the bolded variables from Table 4 which are statistically significant. Another test is the $\mathrm{F}$ test that has zero probability 
associated, a fact which supports the validity of the model for a confidence level of $95 \%$. We used to combat heteroskedasticity the GLS estimation method.

Analyzing the data from Tables 4 and 5, from an economic perspective, it can be observed a positive influence of the variables BONUS_CEO, BDFEM, SALARY_CEO, TENURE_CEO, and YLIST on the financial performance quantified by ROA. It was expected that the remuneration variables to have a positive influence on the economic return, also known as the manager's return. Through compensations, the CEO is incentivized to raise the performance of the company because these kinds of compensations are linked to performance indicators.

However, it appears that the influence of bonuses on financial performance is very low, aspects explained by the fact that in the post crisis period, the CEOs of companies from the US received bonuses reduced or even have not received at all, as a penalty, but also as reducing expenses in front of the uncertain environment. In most studies, company size has a mixed influence on the financial performance. Among the studies recorded by the literature about the link between the CEO's compensations and the financial performance, there is the study of Perry (2006) who demonstrated the existence of a positive connection between the two. Perry (2006) concluded that the CEOs take better decisions if they are rewarded in the form of bonuses. Kang et al (2006) obtained positive correlation between CEO's compensations and financial performance. Hence we have demonstrated the Hypothesis $\mathrm{H}_{3}$ regarding the existence of a positive link between CEO's compensation and financial performance.

The number of women in the Board of Directors as a variable of corporate governance has a positive influence on ROA. The explanation can be attributed to the fact that they are more balanced in their decisions and present a higher risk aversion than men do. Women will take less risky decisions that could affect the company's performance and the performance indicator, ROA. Women as CEOs have the ability to use more efficiently the company assets, especially human resources, being close to employees and they have a better understanding of their personal problems. Women's creativity combined with the sensitivity can bring new ideas and concepts in the company. Similar results can be found in the study of Fidanoski et al (2013) who obtained a negative correlation between the women ratio within the Board and proxy indicators for financial performance such as ROA and ROE. Thus, for the analyzed companies we checked the Hypothesis $\left(\mathrm{H}_{1}\right)$.

The tenure of CEO is in close relation with human nature. This variable has a positive influence, attributed to the fact that a higher seniority implies more professional experience. The long tenure in the same company makes the manager fully understand all the mechanisms operating within that company and he knows the real financial performance to which the company is able to reach. However, in the literature, some authors consider that long tenure can have negative effects, because the manager is sure of his position and his experience and thus, he can take risky decisions that might have negative effects on the financial performance of the company. Boone et al (2007) obtained a negative correlation between the CEO's tenure and financial performance measured through market indicators (MBR) for US companies. With these results, we did not check the Hypothesis $\left(\mathrm{H}_{6}\right)$ regarding the link between CEO's tenure and financial performance.

We obtained negative influence on financial performance measured with ROA from the governance variables such as BDSIZE, CEO_DUAL and BDINDEP. We checked the Hypothesis $\left(\mathrm{H}_{2}\right)$ regarding the existence of a negative link between the non-executive members and financial performance. With the correlation obtained for BDSIZE and ROA we did not check the Hypotesis $\left(\mathrm{H}_{5}\right)$. The economic explanation which can be attributed to these results is linked to the costs associated to these 
kinds of variables. The efficiency of the Board of Directors is not given by the large number of members or by the number of independent members. It must be found an optimal level of members to ensure maximum financial performance, reflected by the economic and financial returns. The associated costs will induce a fall in the net profit observable at the level of financial performance indicators. Similar results were registered by Bhagat and Black (2000). Guest (2008) used as proxy for performance ROA and obtained a negative correlation between financial performance and the number of independent members from the Board of Directors inside companies from the US. Erkens et al (2012) also obtained similar results for US companies.

The variable for duality of the CEO registered a negative influence on financial performance, a fact which is explained by the idea that a manager who has the position of the CEO and Chairman at the same time obtains an overgrown power of control. As we find repeatedly in history, a person with great power has the propensity to abuse it. In case of duality, a CEO can be influenced by the dominance effect and can take wrong financial decisions, believing that he has absolute control, but that decisions can affect the financial performance on long term perspective. Another possible explanation is that the duality may give the CEO an excessive influence and control over other members of the Board of Directors or over the subordinates, inducing a state of irritation and indignation because of the abuse of control, or the abuse of hierarchical superiority (the authoritarian manner), reducing the employees' productivity by increasing the stress levels. The negative correlation between CEO's duality and financial performance was obtained by Bhagat and Bolton (2008).

Table 6: Model 2 ROE

\begin{tabular}{|c|c|c|c|c|c|c|c|c|c|}
\hline & \multicolumn{3}{|c|}{ ROE } & \multicolumn{3}{c|}{ ROE GLS } & \multicolumn{3}{c|}{ ROE White } \\
\hline & $\begin{array}{c}\text { Coef. } \\
\beta\end{array}$ & $\begin{array}{c}\text { Std } \\
\text { Error }\end{array}$ & $\begin{array}{c}\text { T- } \\
\text { Stat }\end{array}$ & $\begin{array}{c}\text { Coef. } \\
\beta\end{array}$ & $\begin{array}{c}\text { Std } \\
\text { Error }\end{array}$ & T- Stat & $\begin{array}{c}\text { Coef. } \\
\beta\end{array}$ & $\begin{array}{c}\text { Std } \\
\text { Error }\end{array}$ & $\begin{array}{c}\text { T- } \\
\text { Stat }\end{array}$ \\
\hline BONUS_CEO & 0.00 & 0.00 & -1.57 & $\mathbf{0 . 0 0}$ & 0.00 & -2.78 & $\mathbf{0 . 0 0 *}$ & 0.00 & -8.00 \\
\hline BDSIZE & $\mathbf{- 0 . 1 3 *}$ & 0.04 & -2.86 & $\mathbf{- 0 . 0 7 *}$ & 0.03 & -2.66 & $\mathbf{- 0 . 1 3 *}$ & 0.03 & -3.99 \\
\hline CEO_DUAL & $\mathbf{- 0 . 0 5 *}$ & 0.02 & -2.08 & $\mathbf{- 0 . 0 5 *}$ & 0.01 & -5.75 & -0.05 & 0.03 & -1.58 \\
\hline LEV & $\mathbf{0 . 0 4 *}$ & 0.01 & 4.62 & $\mathbf{0 . 0 3 *}$ & 0.01 & 3.26 & 0.04 & 0.03 & 1.55 \\
\hline BDFEM & 0.00 & 0.12 & -0.01 & -0.05 & 0.06 & -0.76 & 0.00 & 0.08 & -0.02 \\
\hline BDINDEP & -0.14 & 0.10 & -1.43 & $\mathbf{- 0 . 1 5 *}$ & 0.05 & -3.06 & $\mathbf{- 0 . 1 4 *}$ & 0.09 & -4.38 \\
\hline RISKC & $\mathbf{- 0 . 1 6 *}$ & 0.06 & -2.53 & $\mathbf{- 0 . 1 4 *}$ & 0.04 & -3.30 & $\mathbf{- 0 . 1 6 * *}$ & 0.09 & -1.75 \\
\hline SALARY_CEO & 0.00 & 0.01 & 0.15 & 0.01 & 0.00 & 1.63 & 0.00 & 0.00 & 0.69 \\
\hline SIZE & 0.01 & 0.00 & 2.02 & $\mathbf{0 . 0 0 * *}$ & 0.00 & 1.74 & $\mathbf{0 . 0 1 *}$ & 0.00 & 3.43 \\
\hline TENURE_CEO & 0.00 & 0.00 & -1.19 & $\mathbf{0 . 0 0 *}$ & 0.00 & -2.94 & $\mathbf{0 . 0 0 *}$ & 0.00 & -3.50 \\
\hline YLIST & $\mathbf{0 . 1 7 *}$ & 0.05 & 3.57 & $\mathbf{0 . 1 6 *}$ & 0.02 & 7.53 & $\mathbf{0 . 1 7 *}$ & 0.01 & 12.76 \\
\hline C & $\mathbf{- 0 . 0 1 *}$ & 0.17 & -0.08 & $\mathbf{- 0 . 1 5 * *}$ & 0.08 & -1.94 & -0.01 & 0.05 & -0.29 \\
\hline
\end{tabular}




\begin{tabular}{|l|c|c|c|}
\hline \multicolumn{1}{|c|}{ R-squared } & 0.32 & 0.65 & 0.32 \\
\hline Adjusted R & 0.28 & 0.63 & 0.28 \\
\hline F-statistic & 7.88 & 31.78 & 7.88 \\
\hline Prob (F-stat) & 0.00 & 0.00 & 0.00 \\
\hline
\end{tabular}

Source: * variables statistically significant for a confidence level of 5\%

** variables statistically significant for a confidence level of $10 \%$

Names of the variables are presented in Table1

Author's computation in Eviews 7

Table 7: The significance of influence exerted on ROE by corporate governance variables

\begin{tabular}{|c|c|c|c|c|c|c|c|c|c|c|c|c|}
\hline $\begin{array}{c}\text { BONUS } \\
\text { CEO }\end{array}$ & BDSIZE & CEO_DUAL & LEV & BDFEM & $\begin{array}{c}\text { BDINDE } \\
\text { P }\end{array}$ & RISKC & $\begin{array}{c}\text { SALARY_ } \\
\text { CEO }\end{array}$ & SIZE & $\begin{array}{c}\text { TENURE } \\
\text { CEO }\end{array}$ & YLIST & C \\
\hline ROE & + & - & - & + & & - & - & & + & + & + & - \\
\hline
\end{tabular}

Source: Author's computation in Eviews 7

From Table 6 it is observed that Model 2, which observes the influence of corporate governance variables on financial performance represented by ROE, shows a high degree of confidence for the coefficients obtained. The degree of confidence is supported by the standard errors. Both indicators of the determination ratio, square and adjusted, have an acceptable level, for the GLS estimation (65\%), a fact which supports the validity of the models analyzed. The Pvalue probability associated with the $F$ test is null so we accepted as valid all three forms of estimation used in Model 2 for a confidence level of $95 \%$. Some indicators seem to support the presence of the autocorrelation. We highlighted by bold form the variables which are statistically significant to be easier to detect. To interpret the results, the information contained in Table 7 is required. There is a positive influence on financial performance exerted by variables BONUS_CEO, LEV, SIZE, TENURE_CEO, and YLIST. The financial return can be interpreted as the sharholders' return. The economic interpretation of the results is the same as the explanations from Model 1, so we have skipped them. Paradoxically, the BONUS_CEO variable is statistically significant but has a very low value as we expected. One explanation for the positive influence on ROE from this form of CEO's compensantion is that the CEOs of the selected companies hold stakes in the companies they are managing and thus, they are stimulated thereby to increase the financial performance. The CEO's compensation is based on ROE. The LEV variable has a positive influence on ROE, which could indicate the presence of the information asymmetry, indirectly. A high indebtedness is preferred by shareholders who like to finance the company's activity with funds from the loans. Also, the Modigliani - Miller theory demonstrated that a company more indebted is more valuable, and because the performance and the value of a company are directly connected, it was expected to achieve a negative influence between LEV and ROE.

The control variable SIZE has an inmportant role in corporate governance and recorded a positive link between corporate governance and financial performance. Similar results were ontained by Al-Haddad et al 2011. The positive influence of the size of the company on $\mathrm{ROE}$ is not surprising. It is natural that a large company uses resources for increasing the financial performance, and a larger size requires a higher number of shareholders who seek and demand high financial performance from the manager. Erkens et al (2012) obtained for US companies similar results using variables as BDSIZE and LEV. Hillier and McColgan (2006), Lasfer (2006) have proved that large firms had a lower performance when they considered in the models the effect of corporate governance. The CEO's tenure has also a positive influence on ROE and the explanation is based on the fact that tenure brings more experience for the CEO. 
From the shareholders' perspective, a long tenure can be a tool used by the CEO to convince them that he should remain in the company because he is able to maintain a proper financial performance. The YLIST variable had a positive correlation with ROE. These results can be linked to the idea that over the time, the company gathered more shareholders precisely because it was powerful, and their investment in the company's shares helped to increase the financial profitability. Thus, it captures the spiral effect of the increasing number of shareholders and the company's financial performance. We disapprove for both Models the Hypothesis $\left(\mathrm{H}_{6}\right)$ about the negative relation between CEO's tenure and financial performance.

The negative influence on financial performanceit can be observed from the variables BDSIZE, CEO_DUAL, BDINDEP, and RISKC. As in the Model 1, the negative correlation exerted by BDSIZE and BDINDEP can be attributed to the costs which must be paid by the shareholders to have a large number of members within the Board of Directors. Negative correlation between the number of nonexecutive members and financial performance was obtained by Hermalin and Weisbach (1991), Yermack (1996); Metrick and Ishii (2002). Regarding the negative correlation between BDSIZE and ROE, similar results were obtained by Haniffa and Hudaib (2006); Cheng (2008), Dutta and Chang (2012). The CEO_DUAL had a negative effect on the financial performance due to reasons linked to human nature. Too much power leads to slippages that may affect the financial performance. Shareholders do not want the CEO to hold two senior-level hierarchical positions inside the company because it can lead to specific problems brought by the informational asymmetry. This is recognized by the codes of governance, since many prohibit the CEO duality. The results support the Hypothesis $\left(\mathrm{H}_{4}\right)$. Paradoxically, the RISKC variable had a negative impact on ROE contrary to the expectations. The only explanation that can be ascribed to this is related to the nature of costs. The shareholders can consider the Risk Committee redundant from the cost perspective. The time when the Risk Committee works is important. If such committee is established after the crisis happened, the shareholders may consider that it is pointless to pay that committee after the hard time has already passed. Erkens et al (2012) have used this variable in the model but they did not obtain statistically significant results.

For the Model 2, the remaining variables were statistically insignificant.

\section{Conclusions}

The aim of this study was to identify a link between variables of corporate governance and financial performance in a context of the human nature. To study this relationship empirically, we used a sample of 51 companies listed on NASDAQ stock market from technology sector. We used two econometric models, the difference between them being the independent variable considered as proxy for financial performance (ROA, ROE). Among corporate governance variables we used the total number of members of the Board of Directors, the number of independent members, gender diversity and specific characteristics of CEO (duality, seniority, remuneration). We used the OLS, GLS methods and the White's method for correcting the heteroskedasticity.

For Model 1, some of the empirical study's hypotheses were verified. The results show that ROA is positively influenced by the share of women in the Board of Directors. This was attributed to the adversity towards risk, characteristic to women. That adversion leads to less risky decisions which can adversely affect the financial performance. The CEO compensation variables have a positive relationship with the economic return, which is expected since we considered ROA as a manager's return. Positive links with financial performance represented by ROA were registered for the variables TENURE_CEO and YLIST. It can be explained by the fact that they provide trust that the company and the CEO can support a financial stability over time. 
We obtained negative correlation between financial performance represented by ROA and governance variables. The results verify the existence of a negative link between the number of the independent members and ROA. Similar negative relation was obtained for the BDSIZE. From the perspective of the manager, a large number of members, regardless of origin within the Board of Directors, is a financial problem regarding the costs, which are reflected negatively on the financial performance. The last variable of corporate governance which negatively impacts the economic profitability is CEO_DUAL, a fact explained by the human nature and much power available to a single man who can get to wrong decisions that may affect the financial performance.

In Model 2 we wanted to study the financial performance in context of corporate governance from the perspective of another category of stakeholders involved in a company - the shareholders. Thus, we chose as proxy for financial performance, the return on equity (ROE) that can be called by some authors as the shareholder's return. The empirical results obtained in the econometric study showed a positive relationship between ROE and CEO's compensation through bonuses and salaries, a surprising fact because the shareholders want lower costs. On the other hand through these compensantions, the informational asymmetry is reduced and this reflects positively on the financial performance. The variables SIZE and LEV had a positive influence on the financial return being a clue that on financial performance there are other influence factors. In fact, the influence of corporate governance variables, although statistically significant, is reduced as the value of the coefficients. It supports the idea that the American companies have the financial performance influenced more by peculiarities of the corporate finance. The variables YLIST and TENURE_CEO have had a positive influence on financial profitability.

Model 2, with financial return as an indicator of performance, presents in the results of the econometric study conducted, negative links similar to Model 1, the difference being the variable RISKC. This variable captures the presence of a Risk Committee in the company and would be expected to have a negative value on the financial performance. The positive result can be attributed to the fact that the analyzed period is post-crisis and a special commission for risk does not have sense, from a financial point of view, being for the shareholders additional costs. For future research we propose increasing the sample of companies, the number of sectors analyzed, by applying complex models of analysis.

\section{References}

1. Adams, R. B., Ferreira, D. (2007). A Theory of Friendly Boards. The Journal of Finance, 62: 217-250. doi:10.1111/j.15406261.2007.01206.x

2. Adams, R. B., Ferreira, D. (2009). Women in the boardroom and their impact on governance and performance. Journal of Financial Economics, 94(2), 291-309

3. Aebi V., Schmid M., and Sabato G. (2012). Risk Management, Corporate Governance, and Bank Performance in the Financial Crisis. Journal of Banking \& Finance, Volume 36, Issue 12, December 2012, Pp. 3213-3226. http://dx.doi.org/10.2139/ssrn.1942896

4. Al-Haddad, W., Alzurqan, S. T., \& Al_Sufy, F. J. (2011). The Effect of Corporate Governance on the Performance of Jordanian Industrial Companies: An empirical study on Amman Stock Exchange. International Journal of Humanities and Social Science, 1(4), 55-69.

5. Albring S., Robinson D., Robinson M., (2013). Audit committee financial expertise, corporate governance, and the voluntary switch from auditor-provided to nonauditor-provided tax services. Advances in Accounting, Incorporating Advances in International Accounting, Vol. 30, Issue 1, June 2014, Pp. 81-94, doi:10.1016/j.adiac.2013.12.007

6. Al-Najjar, B. (2014). Corporate 
governance, tourism growth and firm performance: Evidence from publicly listed tourism firms in five Middle Eastern countries. Tourism Management, 42, 342351.

http://dx.doi.org/10.1016/j.tourman.2013. 09.008

7. Ammann M, Oesch D, Schmid M., (2011). Corporate governance and firm value: International evidence. Journal of Empirical Finance, vol. 18, pp.36-55

8. Andrei, T., R. Bourbonnais, (2008). Econometrie. Ed.Economică Bucureşti

9. Armstrong, C., Blouin, J. L., Jagolinzer, A. D., Larcker, D. F. (2015). Corporate Governance, Incentives, and Tax Avoidance. Journal of Accounting and Economics, 60(1): 1-17. http://dx.doi.org/10.1016/j.jacceco.2015.0 2.003

10. Bhagat, S., \& Black, B. S. (2000). Board independence and long-term firm performance. Stanford Law School, Working Paper No. 185. Retrieved from http://leeds-

faculty.colorado.edu/bhagat/bb-

031700.doc

11. Bhagat, S., \& Bolton, B. (2008). Corporate governance and firm performance. Journal of Corporate Finance, 14(3), 257-273. http://dx.doi.org/10.1016/j.jcorpfin.2008.0 3.006

12. Bhagat, S., Bolton J., Subramanian, A. (2010). CEO Education, CEO Turnover, and Firm Performance. Working Paper Series, University of Colorado at Boulder Department of Finance, University of New Hampshire, Georgia State University

13. Bae, S.C., Chang, K., Kang, E., (2010). Culture, corporate governance, and dividend policy: international evidence. Journal of Financial Research, 2012, vol. 35, issue 2, pages 289-316

14. Bebchuk, L.A., Fried, J.M. (2003). Executive compensation as an agency problem. Journal of Economic Perspectives, 17(3), 71-92.

15. Beekes, Wendy and Hong, Alex and Owen, Sian A., An Alternative Measure of Corporate Governance Using Discrete Principal Component Analysis (June 9, 2010).

http://dx.doi.org/10.2139/ssrn.1623005

16. Beltratti, A., Stulz, R., (2012). The credit crisis around the globe: why did some banks perform better?. Journal of Financial Economics, Vol.105, Issue 1, July, Pp. 1-17, doi:10.1016/j.jfineco.2011.12.005

17. Berger A., Kick T., Schaeck K., (2014). Executive board composition and bank risk taking. Journal of Corporate Finance, Vol. 28, October, Pp. 48-65, doi:10.1016/j.jcorpfin.2013.11.006

18. Boone, A. L., Field, L. C., Karpoff, J. M., \& Raheja, C. G. (2007). The determinants of corporate board size and composition: An empirical analysis. Journal of Financial Economics, 85(1), 66-101. http://dx.doi.org/10.1016/j.jfineco.2006.05 .004

19. Bushee, Brian J., Jung, Michael J., Miller, Gregory S., (2013). Do Investors Benefit from Selective Access to Management? (July 11 , 2013). http://dx.doi.org/10.2139/ssrn.1880149

20. Cheng, S. (2008). Board size and variability of corporate performance. Journal of Financial Economics. Vol.87. No.2. 157-176.

21. Coates John C., Kraakman R., (2010). CEO Tenure, Performance and Turnover in S\&P 500 Companies (May 2). ECGI - Finance Working Paper No. 191/2007; Harvard Law and Economics Discussion Paper No. 595.

http://dx.doi.org/10.2139/ssrn.925532

22. Core, J., Larcker, D. (2002). Performance consequences of mandatory increases in executive stock ownership. Journal of Financial Economics, Vol. 64, Issue 3, June, Pp. 317-340, doi:10.1016/S0304-405X(02)00127-7 
23. Drobetz W., Schillhofer, A., and Zimmermann, H. (2003). Corporate Governance and Firm Performance: Evidence from Germany. Center of Finance \& Risk Management. Gutenberg University. Working Paper. No.146. 1-48.

24. Dutta, S.; Chang, B., (2012). Dividends and Corporate Governance: Canadian Evidence. The IUP Journal of Applied Finance. Vol.18. No.4. 5-30.

25. El Baroudy S., Levine R., Shao L. (2008). CEO Compensation for Major US Companies in 2006, Stanford Institute for Economic Policy Research: SIEPR Discussion Paper no. $07-28$

26. Erkens, D. H., Hung, M., Matos, P. (2012). Corporate governance in the 20072008 financial crisis: Evidence from financial institutions worldwide. Journal of Corporate Finance, 18(2): 389-411. http://dx.doi.org/10.1016/j.jcorpfin.2012. 01.005

27. Fidanoski, F., Mateska, V., \& Simeonovski, K. (2014). Corporate governance and bank performance: Evidence from Macedonia. Economic Analysis, 47(1-2), 76-99.

28. Frydman, Carola, Dirk Jenter. CEO Compensation. Annual Review of Financial Economics, vol. 2 (2010): 75-102. http://dx.doi.org/10.1146/annurev-

financial-120209-133958

29. Giannetti M., Yafeh Y., (2012). Do Cultural Differences Between Contracting Parties Matter? Evidence from Syndicated Bank Loans. Management Science, Vol. 58, Issue 2, pp. $365 \quad$ - 383, http://dx.doi.org/10.1287/mnsc.1110.137 8

30. Guest, P. M. (2008). The determinants of board size and composition: Evidence from the UK. Journal of Corporate Finance, 14(1), 51-72. http://dx.doi.org/10.1016/j.jcorpfin.2008.0 1.002

31. Gupta K, Krishnamurti C, Tourani-Rad A. (2013). Is corporate governance relevant during the financial crisis?. Journal of International Financial Markets, Institutions and Money, Vol. 23, February, Pp. 85-110, doi:10.1016/j.intfin.2012.10.002

32. Haldane, A. G. (2011a). Capital discipline. Retrieved from www.bankofengland.co.uk/publications/sp eeches/2011/speech484.pdf

33. Haldane, A. G. (2011b). Control rights (and wrongs). Retrieved from http://www.bankofengland.co.uk/publicati ons/Documents/speeches/2011/speech52 5.pdf

34. Haniffa, R., Hudaib, M. (2006). Corporate governance structure and performance of Malaysian listed companies. Journal of Business Finance \& Accounting, 33, 1034e1062.

35. Hermalin, B., E., Weisbach, M. S., (2003). Boards of Directors as an Endogenously Determined Institution: A Survey of the Economic Literature. Economic Policy Review, Vol. 9, No. 1, April 2003. http://ssrn.com/abstract=794804

36. Hillier, D., McColgan, P., (2006). An analysis of changes in board structure during corporate governance reforms. European Financial Management 12, 575607.

37. Holderness, Clifford G., (2010). Blockholders are More Common in the United States than You Might Think. Journal of Applied Corporate Finance, Vol. 22 , Issue 4 , pp. $75-85$

38. Honoré F., Munarib F., Bruno van Pottelsberghe de La Potterie, (2015). Corporate governance practices and companies' R\&D intensity: Evidence from European countries. Research Policy, Volume 44, Issue 2, March 2015, Pages 533-543, doi:10.1016/j.respol.2014.10.016

39. Itturalde, D. T., Maseda, D. A., Arosa, D. B. (2011). Insiders Ownership and Firm Performance. Empirical Evidence. International Research Journal of Finance and Economics, 67, 120. 
40. Jensen, M. C., Meckling, W. H. (1976). Theory of the firm: Managerial behaviour, agency costs and ownership structure. Journal of Financial Economics, 3(4), 305360.

41. Kanagaretnam, K., Lobo, G.J., Whalen, D.J. (2007). Does good corporate governance reduce information asymmetry around quarterly earnings announcements?. Journal of Accounting \& Public Policy, 26(4), 497-522.

42. Kang T., Hope O-K., Bhat G., (2006). Does corporate governance transparency affect the accuracy of analyst forecasts? Accounting and Finance, vol. 46, pp. 715732

43. Khan, W. A. \& Vieito, J. P. (2013). CEO gender and firm performance. Journal of Economics and Business, Vol. 67, May-June, Pp.

doi:10.1016/j.jeconbus.2013.01.003 $55-66$,

44. Kotler P., Casoline J. (2009). Chaotics. American Management Association, 1601 Broadway, New York

45. La Porta, R., Lopez-de-Silanes, F., Shleifer, A., \& Vishny, R. (1999). Legal determinants of external finance. The Journal of Finance, 52(3), 1131-1150. http://dx.doi.org/10.1111/j.15406261.1997.tb02727.x

46. Lasfer, M. A. (2006). The interrelationship between managerial ownership and board structure. Journal of Business Finance \& Accounting, 33(7-8), 1006-1033.

http://dx.doi.org/10.1111/j.1468-

5957.2006.00600.x

47. Lee, Y.-H., Huang, Y.-L, Hsu, S.-S., Hung, C.H. (2013). Measuring the efficiency and the effect of corporate governance on the biotechnology and medical equipment industries in Taiwan. International Journal of Economics and Financial Issues, 3(2), 662-672.

48. Li K., Wu J., Jiang Y., Hassan Z., Lv Q., Shang L., Maksimovic D. (2010). Large- scale battery system modeling and analysis for emerging electric-drive vehicles. Proceedings of the 16th ACM/IEEE international symposium on Low power electronics and design, pp. 277-282

49. Loderer C., Urs Waelchli U., (2011). Firm age and performance. MPRA Paper No. 26450, University of Bern, ECGI. https://mpra.ub.uni-muenchen.de/26450/

50. Mashayekhi, B., Bazaz, M. S. (2008). Corporate Governance and Firm Performance in Iran. Journal of Contemporary Accounting \& Economics, 4(2), 156-172. http://dx.doi.org/10.1016/S18155669(10)70033-3

51. McCahery, J. A., Sautner, Z., Starks, L. T.,(2015). Behind the Scenes: The Corporate Governance Preferences of Institutional Investors (June 2015). Journal of Finance, Forthcoming. http://dx.doi.org/10.2139/ssrn.1571046

52. Metrick, A., \& Ishii, J. (2002). Firm-level corporate governance. Paper presented at Global Corporate Governance Forum Research Network Meeting, Washington, D.C.

53. Monks, R. A. G.., \& Minow, N. (2011). Corporate governance (5th Edition). New York: John Wiley \& Sons.

54. Ozkan, N. (2006). Do corporate governance mechanisms influence CEO compensation? An empirical investigation of UK companies. Journal of Multinational Financial Management, 17(5), 349-364. http://dx.doi.org/10.1016/j.mulfin.2006.08 .002

55. Perry, Tod (2000). Incentive Compensation for Outside Directors and CEO Turnover (June). Presented at Tuck-JFE Contemporary Corporate Governance http://dx.doi.org/10.2139/ssrn.236033

56. Shleifer, A., \& Vishny, R. W. (1997). A survey of corporate governance. Journal of Finance, 52(2), 737-783. http://dx.doi.org/10.1111/j.1540-

6261.1997.tb04820.x 
57. Stulz, R.M., Williamson, R., (2003). Culture, openness, and finance. Journal of Financial Economics 70, 313-349.

58. Turner, J. D. (2009). The last acre and sixpence': Views on bank liability regimes in nineteenth-century Britain. Financial History Review, 16(2), 111-127. http://dx.doi.org/10.1017/S09685650099 90047

59. Yermack, D. (1996). Higher valuation of companies with a small board of directors. Journal of Financial Economics, $40,185 \mathrm{e} 212$.

60. IRRCi Research Report, (2014). The Alignment Gap Between Creating Value, Performance Measurement, and Long-Term Incentive Design. New York, http://irrcinstitute.org/pdf/alignmentgap-study.pdf

61. OECD: Corporate Governance Factbook, February 2014, available at www.oecd.org 